Barbara P. Herceg Pakšić, Ph.D., Assistant professor

University J.J. Strossmayer Osijek

Faculty of Law

bhercegpaksic@gmail.com

\title{
A CONTRIBUTION TO SLAVERY DEBATE: DOMESTIC LABOUR OF MIGRANT CHILDREN IN FOCUS
}

\begin{abstract}
Slavery and connected practices are ostensibly forgotten phenomenons, often considered they belong to the past. However, the migrant movements are placing focus on these forbidden practices and they are getting new features. The purpose of this paper is to (re)consider specific cases, those with European Court of Human Rights epilogue, where children were victims. Taking into account contemporary considerations on slavery and related practices we question the outcome analyzing key elements related to slavery notion. Emphasis is placed on insufficiently functional definitions in this area, the uncertainity of assessment criteria and comparison to judgments made by other courts. Considering that European Convention of Human Rights is described as the most powerful human rights protection mechanism with great impact on national (criminal) law systems, we search to see how the Convention ban is brought to life, analyze recent developments in this area, offering a different perspective to slavery notion.
\end{abstract}

Keywords: Slavery, Servitude, Children, European Convention of Human Rights, Domestic Labour.

\section{INTRODUCTORY REMARKS}

In the latest Report by the Secretary General Thorbjørn Jagland for the Ministerial Session of Council of Europe, emphasized that trafficking for the purpose of labour exploitation is on the rise across Europe and there is a need for renewed

\footnotetext{
* This paper has been presented at the International Scientific Conference Legal Tradition and New Legal Challenges, held on October 3rd and 4th, 2019, at the University of Novi Sad Faculty of Law.
} 
action based on common European standards. ${ }^{1}$ As stressed, part of the difficulty lies in the fact that there is no consensus on the definition of forced labour, which makes it more difficult to tackle. ${ }^{2}$ Report addresses forced labour as 'modern slavery', a real and pressing problem, especially since GRETA (Group of Experts on Action against Trafficking in Human Beings) raised concerns that existing convention obligations are not being met when it comes to this issue. ${ }^{3}$ As announced, addressing this problem is Council of Europe's priority in the years to come. ${ }^{4}$ Vulnerability of the children on the move affected by migration is derived from their unknown surroundings, isolation, lack of financial means and lack of legal protection. They are faced with limited access to justice, education, social and health services and often suffer persistent violations of their human rights. In asylum and immigration procedures, detention is used instead of child welfare protection, there is high risk of trafficking and exploitation and violations of nonpunishment provisions, ${ }^{5}$ they are rarely considered as rights bearers, ${ }^{6}$ stateless status cause loopholes in child protection frameworks. The manner of arriving to specific country is often the result of criminal activities: smuggling or trafficking of human beings, illegal border crossing, document forgery...etc. Countries, affected with migration challenges, have different ways in dealing with them, ${ }^{7}$ many

${ }^{1}$ Ready for future challenges- Reinforcing the Council of Europe, Report by the Secretary General for the Ministerial Session in Helsinki, 16-17 May 2019, April 2019, at 26.

${ }^{2}$ Ibid, at 28.

3 7th General Report on GRETA Activities. March 2018. Available online at rm.coe.int/ greta-2018-1-7gr-en/16807af20e, accessed 25 January 2019. GRETA has established that trafficking for the purpose of labour has been on the rise for the last decade and is the predominant form of exploitation in some countries.

${ }^{4}$ Ready for future challenges- Reinforcing the Council of Europe, supra note 1 at 28.

${ }^{5}$ Non-punishment provision comprehends that victims of trafficking should not be held responsible for crimes that they were compelled to commit, including administrative and immigration-related offences.

${ }^{6}$ Often subjected to collateral damage of decisions connected to adults status, refugee status (as subordinate to alien/non-citizen status), all sorts of punitive or deterrence measures and actions aimed at suppressing new arrivals such as immigration detention, denial of education, medical assistance, social help, family reunification, non refoulment principle...etc. Children should be regarded as right bearers in law. They are not mini adults but have separate identities, needs and characteristic. Jacqueline Bhabha and Wendy Young, 'Not Adults in Miniature: Unaccompanied Child Asylum Seekers and the New US Guidelines'11 International Journal of Refugee Law (1999) 84-125, at 87.

${ }^{7}$ Some are detrimental leading to direct human rights violations. For example, Australia has adopted policies based on punitive measures as the 'only way to deter irregular migration' Mary E. Crock, 'Of Relative Rights and Putative Children: Rethinking the Critical Framework for the Protection of Refugee Children and Youth' 54 Australian International Law Journal (2013) 33-53 at 34. The author suggests that this has led to objectification of migrant children and denial of their status as right bearers. Hungary has built second fence on border with Serbia to keep migrants out. The first section of barbed wire was built along the 175-kilometre border between Hungary and Serbia in the summer of 2015, then along most of the frontier with Croatia, available at www.euronews.com/2017/04/28/ hungary-completes-new-anti-migrant-border-fence-with-serbia, accessed 25 June 2019. 
resulting in tragic outcomes. ${ }^{8}$ Paper is oriented to slavery and connected practice in cases with children as victims. Article 4 of European Convention for Human Rights and Fundamental Freedoms (ECHR) guarantees freedom from slavery, servitude and forced labour, but at the same time reports on violations exist. ${ }^{9}$ Some of the most prevalent child slavery forms are child trafficking, commercial sexual exploitation, bonded child labour, forced work in mines, forced agricultural labour, child soldiers/combatants, forced child marriage and domestic slavery. ${ }^{10}$

The topic specificity and relevance lie in re-examining relevant decisions in order contribute to contemporary understanding of slavery. Methodologically speaking, it is a qualitative approach of phenomenological type and specific paradigm regarding the views on slavery. In this purpose, we try to answer is the accepted slavery notion functional and how it is comprehended in practice of European Court for Human Rights (ECtHR). The given conclusion leads us to raise the need for alteration of slavery interpretation in contemporary society circumstances.

\section{ADDRESSING SLAVERY ON INTERNATIONAL SCALE: SHORT OVERVIEW AND CONTEMPORARY CONTEXT}

Slavery was the first human rights issue addressed on international scale. ${ }^{11}$ The first international document that condemned the slave trade was Declaration relative to the Universal Abolition of the Slave trade from 1815 that came into

\footnotetext{
${ }^{8}$ Available at www.theguardian.com/world/2017/jun/21/trial-begins-over-deaths-of-71migrants-in-refrigerated-lorry, accessed 17 July 2019.

${ }^{9}$ Statement that Migrant Rights Centre Ireland has dealt with hundreds of cases most likely to be found among migrants used as domestic workers and cleaners, restaurant and catering workers and in horticulture. David Keane, 'Abolitionist At Heart but not in Action, Slavery, Servitude and the Status of Art. 4 ECHR in Irish Law' 50 Irish Jurist (2013) 166-198, at 187. In Mali, young girls go into risky domestic work. Mauretania has great challenges in supressing slavery practiceslavery was abolished in 1980, criminalized in 2007 and less than a decade later, in 2015, it became a crime against humanity punishable by up to 20 years in prison. It is not known how many people in Mauritania today live in slavery. It is believed to have been in decline due to successive Mauritanian laws and programmes developed to eradicate slavery. Despite laws, programmes and difference of opinion with regard to the existence of slavery in Mauritania, the Special Rapporteur concluded that de facto slavery continues to exist in Mauritania. See, Report of the Special Rapporteur on contemporary forms of slavery, including its causes and consequences, Gulnara, United Nations, General Assembly, A/HRC/15/20/Add.2, 16 August 2010, pp 2-5. In United Kingdom, child domestic slavery is a growing phenomenon. Available at www.crin.org/en/library/publications/ united-kingdom-child-domestic-slavery-growing-phenomenon-uk, accessed 17 July 2019.

${ }^{10}$ Available at www.crin.org/en/library/publications/forms-violence-slavery, accessed 17 July 2019.

${ }^{11}$ Lucas Knott, 'Unocal Revisited: On the difference between Slavery and Forced Labor in International Law’ 28 Wisconsin International Law Journal (2010) 201-233, at 212.
} 
force in $1927 .{ }^{12}$ Convention to Suppress the Slave Trade and Slavery from 1926 defined slavery as ... the status or condition of a person over whom any or all of the powers attaching to the right of ownership are exercised. ${ }^{13}$ To this time, this definition is the 'baseline for understanding slavery'. ${ }^{14}$ The Supplementary Convention on the Abolition of Slavery, The Slave Trade and Institutions and Practices similar to Slavery accepted this definition in Art. 7a, and added that a slave means a person in such condition or status. ${ }^{15}$ Although widely accepted, the provision expression leaves room for alternative interpretations, but to this date, there has been no consensus about the need of its change. This does not mean that its standard interpretation is without questioning. Rome statute forbids enslavement from $1998 .{ }^{16}$ Prohibition is in all major international human rights treaties and is one of the rare ius cogens principles that creates erga omnes effect. ${ }^{17}$

Understanding that slavery belongs to past phenomena has been outdated. Recent movements in human rights and migrations area, place mostly ex -post fact but increased focus on it. It is considered that all the countries in the world (besides Korea) have some form of slavery prohibition. ${ }^{18}$ Their meaning can be

12 The abolitionist movement began as an effort to stop the Atlantic slave trade and to free slaves in the colonies of European countries and in the United States. It has been estimated that between 1815 and 1957 some 300 international agreements were implemented to suppress slavery. None has been totally effective. David Weissbrodt and Anti-Slavery International (Michael Dottridge). Abolishing Slavery and its Contemporary Forms, Office of the United Nations High Commissioner for Human Rights. United Nations New York and Geneva HR/PUB/02/4 2002, at 3.

${ }^{13}$ Art. 1, para. 1, Convention to Suppress the Slave Trade and Slavery, 1926, 46 Stat. 2183, Treaty Series 778.

14 Jean Allain and Robin Hickey, 'Property and definition of slavery' 61 International and Comparative Law Quarterly (2012) 915-938, at 916.

15 The Supplementary Convention on the Abolition of Slavery, The Slave Trade and Institutions and Practices similar to Slavery 1956, UNTS 266, I. Nos 3822-3833. Slavery means, as defined in the 1926 Slavery Convention, the status or condition of a person over whom any or all of the powers attaching to the right of ownership are exercised, and 'slave' means a person in such condition or status.

${ }^{16}$ Enslavement is a form of crime against humanity, and according to Art. 7 (2) (c) means the exercise of any or all of the powers attaching to the right of ownership over a person and includes the exercise of such power in the course of trafficking in persons, in particular women and children.

${ }^{17}$ International Court of Justice, Barcelona Traction, Light and Power Company, Limited, Belgium v. Spain, Second Phase, 05 February 1970 'In view of the importance of the rights involved, all States can be held to have a legal interest in their protection; they are obligations erga omnes. Such obligations derive, for example, in contemporary international law, from the outlawing of acts of aggression, and of genocide, as also from the principles and rules concerning the basic rights of the human person, including protection from slavery and racial discrimination'. Available at www.icj-cij.org/files/case-related/50/050-19700205-JUD-01-00-EN.pdf 1212 2017, p. 32, paras. 33-34, accessed 20 August 2019; See also M. Cherif Bassiouni, 'International Crimes: Jus Cogens and Obligations Erga Omnes' 4 Law and Contemporary Problems (2013) pp. 63-74.

${ }^{18}$ David Tolbert and Laura A. Smith, 2016. 'Complementarity and the Investigation and Prosecution of Slavery Crimes'14 Journal of International Criminal Justice (2016) 429-451, at 430. 
seen in more of symbolic way since practical efficiency and significance is questionable. ${ }^{19}$ Due to specific circumstances (some influenced through ECtHR decisions), certain countries have sufficiently recognized the problem and adopted a new legislation or amended previous. On March 26 2015, United Kingdom adopted Modern Slavery Act. ${ }^{20}$ One of the recent is Australia, adopting Modern Slavery Act in 2018, which commenced on 01 January 2019. ${ }^{21}$ Several other countries are contemplating modern slavery legislation, including Switzerland, Germany and Canada. ${ }^{22}$ Recently, faced with severe forms of exploitation, courts highlighted their reasoning of the 'modern slavery' or 'contemporary slavery' notion. ${ }^{23}$ Slavery

However, some author define this utter criminalization as a fallacy. Also, Vladislava Stoyanova, 'Article 4 of ECHR and the obligation of Criminalizing Slavery, Servitude, Forced labour and Human trafficking' 3 Cambridge Journal of International and Comparative Law (2014) 407-443 at $429, \mathrm{n} 88$.

${ }^{19}$ See the claim supra $n$ 12. In addition, as no cases based on the Mauritanian 2007 Slavery Act have been brought before the courts, the Special Rapporteur was informed that the Ministry of Justice is setting up a commission to review the law and provide suggestions on how to strengthen it. The Government does not have definitive data on the nature and incidence of slavery in Mauritania, which further exacerbates the problem of properly addressing slavery. Although forms of slavery such as serfdom have been reported in Mauritania, the law makes no reference to them. Either the cases were reclassified and filed under a different name such as 'inheritance or land dispute' or were not pursued owing to insufficient documentary evidence, or the person who put forward the claim was put under pressure from her extended family, master or sometimes local authorities to retract her claim. This results in cases never being reported as 'slavery' cases and therefore - judicially - slavery cases do not exist. Report of the Special Rapporteur on contemporary forms of slavery, including its causes and consequences, supra $n 9$ at p. 16 and pp. 18-19.

${ }^{20}$ Available at www.legislation.gov.uk/ukpga/2015/30/contents/enacted, accessed 25 August 2019.

${ }^{21}$ Australia's potential modern slavery act was introduced and modelled after the UK's Modern Slavery Act in 2015. Modern Slavery Act No. 153, 2018, C2018A00153. Modern slavery means conduct which would constitute: (a) an offence under Division 270 or 271 of the Commonwealth Criminal Code; or (b) an offence under either of those Divisions if the conduct took place in Australia; or (c) trafficking in persons, as defined in Art. 3 of the Protocol to Prevent, Suppress and Punish Trafficking in Persons, Especially Women and Children, supplementing the United Nations Convention against Transnational Organized Crime, done at New York on 15 November 2000 ([2005] ATS 27); or (d) the worst forms of child labour, as defined in Art. 3 of the ILO Convention (No. 182) concerning the Prohibition and Immediate Action for the Elimination of the Worst Forms of Child Labour, done at Geneva on 17 June 1999 ([2007] ATS 38).

${ }^{22}$ Ramachandra Komala, 'Australia Starts Tackling Modern Slavery. New South Wales Adds Penalties for Offenders Under State Law' Human Rights Watch, available on www.hrw.org/ news/2019/01/09/australia-starts-tackling-modern-slavery, accessed 25 September 2019.

${ }^{23}$ Virginia Mantouvalou, 'The Many Faces of Slavery: the Example of Domestic Work' 2012, available at www.academia.edu/1522698/The_Many_Faces_of_Slavery_The_Example_of_Domestic_Work, accessed 10 April 2019. New forms emerge and spread under contemporary slavery notion. It is said that this term covers traditional slavery, the institutions and practices similar to slavery such as debt bondage, serfdom, forced marriage and forced labour. UN Human Rights Council (2017) Report of the Special Rapporteur on contemporary forms of slavery including its causes and consequences, A/HRC/36/43, pp. 3-4. 
is challenged with determination where it exists and starts. ${ }^{24}$ Article 1 of Slavery Convention declares it's unacceptability and should be seen as the common denominator on which every state could agree. ${ }^{25}$ Some authors point out that mentioned slavery definition is insufficient since it is connected to legal concept of (the right of) ownership, leaving other forms without evidence of the master-property relationship. ${ }^{26}$ According to Allain, there is an acute need to establish a proper understanding of slavery definition in international law, since the start of 21 century. ECtHR and International Criminal Tribunal for the former Yugoslavia (ICTY) have represented contradictory determinations where slavery is concerned. ${ }^{27}$ Elaborating further in this paper, contradictory positions are based on applied slavery notion: ECtHR uses de iure and ICTY de facto notion of slavery, which then leads to distinct decision-making process and result.

\section{SLAVERY AND SERVITUDE: SCENARIOS AND LEGAL RESPONSE}

Besides specific judgement proclamation and derived State obligations, influence of the ECtHR to national systems is a well-recognized fact- precise notions meaning, concept-developing role, interpretation through relevant international and national acts... ${ }^{28}$ ECHR provides an absolute prohibition in Article $4{ }^{29}$ and comprehends positive rather than negative State obligations, since the perpetrator will usually be individuals..$^{30}$ Authors point out the hierarchy in terms of violation

${ }^{24}$ Knott, supra n 11 at 209.

${ }^{25}$ Ramona Vijeyarasa and Jose Miguel Bello Villarino, 'Modern Day Slavery-a Judicial Catchall for Trafficking, Slavery and Labour Exploitation: A Critique of Tang and Rantsev' 38 Journal of International Law and International Relation (2013) 38-76, pp. 55-56.

${ }^{26}$ Ibid.

27 Jean Allain, 'The Definition of Slavery in International Law'52 Howard Law Journal (2009) 239-275, at 242.

${ }^{28}$ Court follows analytical framework-first it interpretes the material scope of the right invoked (how should for example slavery be defined), which is definitional stage, proceeds with clarifying the obligations imposed upon states which is an application stage. Vladislava Stoyanova, Human Trafficking and Slavery Reconsidered, Conceptual Limits and States'Positive Obligations (Cambridge University Press, 2017) at 219.

${ }^{29}$ Art. 4., Prohibition of slavery and forced labour. 1. No one should be held in slavery or servitude. 2. No one shall be required to perform forced or compulsory labour. 3. For the purpose of this Article, the term 'forced or compulsory labour' shall not include any work required to be done in the ordinary course of detention imposed according to provisions of Art. 5 of this Convention or during conditional release from such detention; any service of a military character, or in case of conscientious objectors in countries where they are recognized, service exacted instead of compulsory military service; any service exacted in case of emergency or calamity threatening the life or well-being of the community; any work or service which forms part of normal civic obligations.

${ }^{30}$ Wiliam A. Schabas, The European Convention of Human Rights, A Commentary (Oxford University Press, 2015) at 206. 
severity. Slavery (requiring ownership), servitude (requiring forced labour coupled with compulsion to live on another's property) and forced labour (involuntary work extracted under menace with no proprietary element). ${ }^{31}$ Compared to some other rights and freedoms, slavery prohibition is brought to life only through few ECtHR judgments, even less when it comes to children victims. To interpret this, we could question the national competent authorities understanding manner, victims' rights awareness, ${ }^{32}$ unsuccessful case handling and slavery notion comprehension in general ${ }^{33}$ but parri pasu ECtHR know how in specific cases.

Siliadin v. France ${ }^{34}$ was the first ECtHR case regarding Article $4 .{ }^{35}$ Applicant arrived in France with Mrs. D. in January 1994, with a passport and a tourist visa. She had 15 years and 7 months. It was arranged that she would attend school and work for Mrs. D. at her home (until the cost of her air ticket had been reimbursed). In reality, she became an unpaid house cleaner for Mr. and Mrs. D., her passport was taken. She was 'lent' to Mrs. B, who had two small children, to assist her with household work. Siliadin had to work 15 hours a day for several years, without being paid and days off. During the procedure, she stated she had felt like a house slave. Deciding upon this case, ECtHR confirmed forced labour and servitude but stated slavery as 'the real right of property where a person falls on the object' was not confirmed. Since, for the effective deterrence purpose, Member states have to criminalize and prosecute acts involving slavery, servitude and forced labour, France violated Article 4 ECHR- slavery and servitude were not explicitly part of its Criminal Code. There was only a general provision on labour exploitation, so Mr. and Mrs. D. were not convicted. ${ }^{36}$

${ }^{31}$ Keane, supra n 9 at 171.

32 Barbara Herceg Pakšić and Miroslav Jukić, 'Primjena konvencijskog prava u području zabrane ropstva i prisilnog rada: Europski standardi i hrvatska postignuća' /ECHR Prohibition of Slavery and Forced Labour: European Standards and Croatian Accomplishments/23 Hrvatski ljetopis za kaznene znanosti i praksu, (2016) pp. 281-310.

${ }^{33}$ Besides migration challenges, conceptual connection to trafficking condition new slavery contoures, so clarity and the notions limits covered by Art. 4 ECHR are yet to be seen. From 2010 and Rantsev judgment, trafficking in human beings (THB) came under the scope of Art. 4 ECHR. By its very nature and aim of exploitation, THB is based on the exercise of powers attaching to the right of ownership, described in the explanatory report accompanying the Anti-Trafficking Convention as the modern form of the old worldwide slave trade. See, Guide on Article 4 of the Convention - Prohibition of slavery and forced labour, European Court of Human Rights, 31 December 2018, at 6.

${ }^{34}$ Application No 73316/01, 26 July 2005.

${ }^{35}$ Helen Duffy, 'Litigating Modern Day Slavery in Regional Courts: A Nascent Contribution' 14 Journal of International Criminal Justice (2016) 375-403, at 378. Stoyanova, supra n 10 at 413.

${ }^{36}$ Besides Art. 4 ECHR, other treaties and documents were violated- Arts. 19, 32 and 36 of the Convention on the Rights of the Child; then the Protocol on the Prevention, Suppression and Punishment of Trafficking in Persons, especially Women and Children, the Convention on the Abolition of Slavery, the Supplementary Convention on the Abolition of Slavery and Institutions and Practices similar to Slavery. 
This decision had an effect seven years later, on subsequent case of two Burundian girls exploited in France, C.N. and V.v. France. ${ }^{37}$ France again ${ }^{38}$ violated the Article 4 grounded on inappropriate criminal law framework. The applicants, two sisters born in Burundi with French nationality, arrived in France aged 16 and 10 years, escaping the 1993 Burundi civil war. Mr. and Mrs. M, their relatives with seven children living in France, gain the guardianship. Sisters did all the housework and were used as house cleaners. They gained no access to a bathroom, were not allowed to eat with the family (were given occasional leftovers) and were not paid or given days off. Considering the difference in work between sisters (the older sister did the actual housemaid work), and given the fact that there has been a threat of returning to origin country, this court concluded that only the first sister was subjected to forced labour and servitude. Slavery was not questioned.

Migrant domestic workers are at heightened risk of certain forms of exploitation and abuse ${ }^{39}$ that violate not only slavery prohibition (including servitude and forced labour), but also the right to health, to adequate living standard, including adequate food, right to physical integrity and the prohibition of torture, right to privacy, freedom of movement. It can entail other violations such as religion freedoms, the right to family life. ${ }^{40}$ Exploitation on behalf of diplomatic personnel is a specific problem since many of severe cases face the problem of employers' diplomatic immunity. Slavery prohibition is a peremptory norm (ius cogens), therefore, international treaties or customary rules do not possess the same norma-

${ }^{37}$ Application No 67724/09, 11 October 2012.

${ }^{38}$ In both cases the court's decision relied on the fact that it had already penalized France for failing in its positive obligations to protect victims of forced labour, servitude and slavery, available at www.crin.org/en/library/publications/france-exploitation-case-sees-slavery-criminalised-last, accessed 12 December 2018. Because of these cases, France amended CC provisions in the summer of 2013, introducing five new offences (reduction to slavery, servitude, forced labor, forced services and the removal of organs, with mandating prison sentences of up to 30 years for the most serious offences).

39 According to UN, Committee on Migrant Workers 2011: General Comment on Migrant Domestic Workers: CMW/C/GC/1, 23 February 2011, Introduction, p.7., isolation and dependence are the main reason. The situation often includes the isolation of life in a foreign land and language, distance from family; lack of basic support systems and unfamiliarity with the culture and national labour and migration laws. There is dependence on the job and employer because of migration-related debt, legal status, practices of restricting their freedom to leave the workplace.

${ }^{40}$ Reported cases range from less severe labor law infringements (e.g. no remuneration for overtime work, less wages than agreed beforehand) over severe forms of labor exploitation (wages far below the minimum wage, overlong workings hours, no days off or holidays) to working and living conditions that amount to forced labor and slavery-like practices (low or literally no payment of wages, having to work around the clock, restrictions of liberty, inhuman accommodation and food, physical and sexual violence). Angelika Kartusch, Domestic Workers in Diplomats' Households Rights Violations and Access to Justice in the Context of Diplomatic Immunity. Analysis of Practice in Six European Countries. German Institute for Human Rights (2011) at 5. 
tive strength. However, host countries often remain inactive ${ }^{41}$ In cases where legal proceedings are involved, they are primarily based on labour law and have a form of out- of- court negotiations directed to financial settlements. ${ }^{42}$

\subsection{Intermezzo: Slavery Definition Close Up}

There are different academic (theoretical) and judicial points of view on how we should interpret the existing definition. According to relevant literature on this topic, it seems reasonable to reduce possible interpretation on two viewpoints: de iure and de facto slavery notion. In short, de iure slavery is status as a recognition of slavery in law and de facto slavery is a condition as slavery in fact. ${ }^{43}$ None of the anti-slavery provisions prohibits or limits the interpretation only on one of these two options. Both stands, as discussed later, are represented in specific judicial decisions.

Historical aspect usefully serves for teleological interpretation. ${ }^{44}$ De iure concept, based on slavery status, connects it with ownership or exercise ownership over another person. Law or legal norms are conditioned by status. This position suffers justified objections that can be reduced to one of Gross and Thomas: it would make the Slavery Convention largely irrelevant because de iure slavery is now abolished almost everywhere. ${ }^{45}$ Indeed, modern legal systems do not recognize the possibility of owning another human being (the only living creature someone can legally own is animal) ${ }^{46}$ Nevertheless, this did not prevent the ECtHR from accepting this de iure understanding and thus declining slavery confirmation in Siliadin case. The ECtHR itself acknowledged in the later decision that such a narrow understanding ultimately deprives victims of practical and effective

${ }^{41}$ Ibid, at 6 . This study focuses on practices in Austria, Belgium, France, Germany, Switzerland, and the United Kingdom in their capacity as host states for foreign diplomatic missions and international organizations. For example, alleged rights violations by diplomat employers experienced by private domestic workers notified in France from 2010- 1 case and in United Kingdom 3 cases. See at 20.

42 Ibid, at 38-40.

${ }^{43}$ Allain, supra $\mathrm{n} 27$ at 261.

${ }^{44}$ Allain emphasizes that in the course of new interpretations it is necessary to bear in mind the history of the creation of the Slavery Convention. For example, as proposed in 1925 the draft Art. 2(b) was to bring about progressively and as soon as possible the disappearance of slavery in every form, notably the case of domestic slavery and similar conditions. Ibid at 246. General rule of interpretation from Art. 31 of Vienna Convention on the Law of Treaties, 1969, TS vol 1155: A treaty shall be interpreted in good faith in accordance with the ordinary meaning to be given to the terms of the treaty in their context and in the light of its objects and purpose.

${ }^{45}$ Ariela J. Gross and Chantal Thomas, 'The New Abolitionism, International Law and the Memory of Slavery' 35 Law and History Review (2017) 99-118, at 114.

${ }^{46}$ For example, slavery was associated with ownership sanctioned by the legal system in International Covenant on Civil and Political Rights. This is a limited understanding of what slavery could mean under human rights law today and would imply making it a defunct legal concept. Stoyanova, supra n 28 at 220. 
protection ${ }^{47}$ Keane invites on renewed law, reasoned with reluctance to call slavery anything that is not chattel slavery based on ownership. ${ }^{48}$

On the other hand, de facto notion targets the condition, the performance of actions inherent to property: powers attached to the rights of ownership. Slavery Convention allows us to take his position since slavery 'condition' is a part of its Article 1 provision. It seems more suitable for contemporary exploitative practice but the challenge is there is no direct guidance or criteria, which powers are in focus. Regardless of that, some of the courts have shown the adaptability to contemporary times and applied this stance. For example, the decision of ICTY Appeals Chamber in Kunarac et al case from 2002. ${ }^{49}$ The case was dealing with enslavement as modality of crime against humanity regarding Muslim woman held in detention centres in Foča and other locations in Bosnia and Hercegovina, kept there by Serb forces in 1992 and 1993. This Court accepted the fact that contemporary slavery forms have transformed and outgrown the 'chattel slavery'. ICTY recognized they are grounded on powers attaching to the right of ownership that are not manifested in extreme ways, but encompass juridical personality destruction. In the case of various contemporary forms, the victim is not subject to the exercise of the radical rights of ownership associated with 'chattel slavery', but in all cases, because of the exercise of any or all of the powers attaching to the right of ownership, there is some destruction of the juridical personality... The Appeals Chamber observed that the law does not know of a 'right of ownership over a person' so prepared a list of indicative criteria. They are not numerus clausus and include the 'control of someone's movement, control of physical environment, psychological control, measures taken to prevent or deter escape, force, threat of force or coercion, duration, assertion of exclusivity, subjection to cruel treatment and abuse, control of sexuality and forced labour'. ${ }^{50}$

The other notable example was High Court of Australia in The Queen v. Tang, from 2008, involving women providing sexual services. ${ }^{51}$ The case against brothel

${ }^{47}$ C. N. and V. v France, para. 121.

${ }^{48}$ Keane, supra $\mathrm{n} 9$ at 167.

${ }^{49}$ International Tribunal for the Prosecution of Persons Responsible for Serious Violations of International Humanitarian Law Committed in the Territory of the Former Yugoslavia since 1991, IT-96-23\& IT-96-23/1-A, 12 June 2002. The Appeals Chamber accepts the chief thesis of the Trial Chamber that the traditional concept of slavery, as defined in the 1926 Slavery Convention and often referred to as 'chattel slavery' has evolved to encompass various contemporary forms of slavery, which are also based on the exercise of any or all of the powers attaching to the right of ownership. Art. 1(1) of the 1926 Slavery Convention speaks more guardedly 'of a person over whom any or all of the powers attaching to the right of ownership are exercised'. See points 117 and 118, Judgment of June 2002, Prosecutor v Dragoljub Kunarac, Radomir Kovač and Zoran Vuković, available at www. icty.org/x/cases/kunarac/acjug/en/kun-aj020612e.pdf, accessed 13 September 2019.

${ }^{50}$ Ibid, point 119.

${ }^{51}$ The Queen v Tang, [2008] HCA 39, 28 August 2008, M5/2008. Available at www.austlii. edu.au/cgi-bin/sinodisp/au/cases/cth/HCA/2008/39.html?stem $=0 \&$ synonyms $=0 \&$ query $=$ title 
owner Wei Tang was the first jury conviction under the slavery offences in Australia. Women, previously providing sexual services in Thailand, voluntarily arrived in Australia to continue with this activity. Each of them was paid USD 20,000 and was required to return USD 45,000 (transport, living and paid sums). They worked for six days a week, reducing their debt by USD 50 per client. They did not speak English, knew no one or what they are facing; they were told that they should be hiding and avoiding immigration officials. Their passports and travel tickets were taken. They were not locked and were well taking care of. Application of de iure term was considered inconsistent with the context and the purpose of the universal nature of Slavery Convention, having in mind that States Parties do not recognize slavery as a legal status. Since the text allows both de iure and de facto understanding, Australian judges developed their own indicators.

In both of mentioned judgments, faced with the challenge of appropriate and up to date slavery understanding as well as the impossibility of ownership over person, courts decided to reject de iure slavery stance and confirmed the slavery through de facto notion. The latter implies ownership powers over a person without legal background. It still exist in law where any or all powers attaching to the right of ownership are exercised, in respect of a person subjected to control tantamount to possession...when a person is controlled as if she were a thing. ${ }^{52}$ This concept is broader than the classic chattel slavery and has two aspects- the perpetrators aspect (concerns control over the victim) and the victim aspect (concerns the freedom of choice). ${ }^{53}$

The important step in further concept development happened in 2012, when Bellagio-Harvard Guidelines on the Legal Parameters of Slavery were adopted (BH Guidelines). ${ }^{54}$ They relate to the 1926 slavery definition, but go a step further in clarification. Execution of the powers inherent to ownership are proclaimed as constituting control over a person in such a way as to significantly deprive that person of his or her individual liberty, with the intent of exploitation through the

(\%222008\%20HCA\%2039\%22, accessed 13 January 2019. See also, Jean Allain, 'R v Tang, Clarifying the Definition of Slavery in International Law'10 Melbourne Journal of International Law 10 (2009) pp. 246-255.

52 Allain and Hickey, supra n 14 at 938.

${ }^{53}$ According to Kolodizner, there are two aspects of de facto slavery: the aspect of the slave, that is, the aspect of his freedom, and how much he is controlled, and the slave owner and the exercise of control which is seen as domination over the victim's freedom of choice. Irina Kolodizner, 'R v Tang: Developing an Australian Anti-Slavery Jurisprudence' 31 Sydney Law Review (2009) 487-497, at pp. 491-495.

${ }^{54}$ Bellagio-Harvard Guidelines on the Legal Parameters of Slavery. Ten guidelines aimed at clarifying the slavery determination based on Art. 1 of the 1296 Slavery Convention and Art. 7 (a) of the 1956 Supplementary Convention. Guidelines are available at www.law.qub.ac.uk/schools/ SchoolofLaw/FileStore/Filetoupload,651854,en.pdf, accessed 10 September 2019. Critics of the proclaimed slavery understanding are arguing that it is circular because the inherent ownership control is again explained by ownership. Gross and Thomas, supra n 45 at 115 . 
use, management, profit, transfer or disposal of that person. Usually this exercise will be supported by and obtained through means such as violent force, deception and/or coercion.

Presented concept has objective and subjective component. The first one aims at establishing a significant liberty deprivation. Deprivation is a synonym for complete subtraction or subjugation, in its essence it is an absolute term. We believe that deprivation of liberty (as a full subtraction) is not necessary to confirm slavery, because then the word 'significantly' is simply redundant. Starting from presumption that the intent was to highlight the considerable control of personal freedom (of movement, choice and decision-making), maybe 'restriction' can operate as more functional concept. To that extent, the objective component of slavery can be understood and interpreted as a major/significant limitation/ restriction of personal freedom aimed at creating of significant dependency relation. ${ }^{55}$ The subjective component includes the perpetrators intent of exploiting the victim in different ways, most often, in labour.

It is considered that 'institutions and practices similar to slavery' have their basis in international law through the 1926 and 1956 Convention. Such practices can reach slavery level as soon as ownership powers are established. This leads to a conclusion of the specific gradation, according to which slavery is the most difficult form of exploitation and the other forms are weaker. ${ }^{56}$ It seems acceptable to comprehend slavery concept as control conducted through significant limitation of personal freedom that includes exploitative practice. This includes de iure (status) and de facto (condition) notion. The standpoints of other authors also go in this direction. ${ }^{57}$ This personal freedom would include the freedom of movement and choice and decision making regarding personal questions. The victim of slavery conduct most often does not have any mechanism or the possibility to alter or modify her situation.

${ }^{55}$ Herceg Pakšić and Jukić, supra n 32 at 290.

56 This kind of relation is comparable to torture- cruel, inhuman and degrading treatment. International bodies uniformly consider factors such as the nature of the acts, the degree of mental or physical harm, the purpose and intent of the interrogators, and the acquiescence or participation of public officials in assessing whether conduct constitutes torture or inhuman or degrading treatment. David Weissbrodt, and Cheryl Heilman, 'Defining Torture and Cruel, Inhuman, and Degrading Treatment' 29 Law \& Inequality, (2011) 343-394, at 393. The legal difference between torture and other forms of ill treatment lies in the level of severity of pain or suffering imposed. In addition, torture requires the existence of a specific purpose behind the act - to obtain information, for example. The distinction between torture and CIDT relates primarily to the question of personal liberty. Manfred Nowak and Elizabeth McArthur, 'The distinction between torture and cruel, inhuman or degrading treatment' 16 Torture (2006) 147-151, at 151.

${ }^{57}$ Jean Allan and Kevin Bales, 'Slavery and its Definitions'14 Global Dialogue 14 Research Paper No. 12-06, (2012) pp. 3-7, available at hydra.hull.ac.uk/assets/hull:9986/content, accessed 15 March 2019. 


\subsection{Stress Test: Re-examining ECtHR Positions}

As mentioned earlier, unlike some other courts, ECtHR interprets slavery as narrow de iure concept, requiring ownership sanctioned by the legal system and following the phrase 'genuine right of legal ownership'. It does not offer any proactive stance of interpreting slavery from a contemporary perspective. ${ }^{58}$ Below we analyse two mentioned judgments to re-examine certain positions and explore possible outcomes according to $\mathrm{BH}$ Guidelines criteria (from guideline 4). Besides the child victim feature, in both cases victims were migrant girls, exploitative practice was regarding domestic work, the country was France and slavery was unconfirmed. In both cases, Article 1 of Slavery Convention was used. We explore other possible manner of reasoning constructing a test managed by $\mathrm{BH}$ Guidelines. $^{59}$

$\mathrm{BH}$ Guidelines suggest that exercise any or all of the powers from the above table shall provide evidence of slavery if they demonstrate control over a person tantamount to possession. ${ }^{60}$ It is visible that in both cases all or almost all Guidelines parameters have been fulfilled. This heads us with a question of control, ${ }^{61}$ a crucial element common to all the forms of exploitation. The importance is stressed in mentioned ICTY positions that chattel slavery is impossible today but what is important is an issue of control. ${ }^{62}$ From psychological aspect, it is connected with victim's vulnerability where slavery conducts seems like permanent situation followed by feelings of fear, abandonment, helplessness, inability to change the situation, threats of being sent back to native country... When children are involved, the situation is worse so control establishment can be an easy for

${ }^{58}$ Stoyanova, supra $\mathrm{n} 28$ at 246.

59 Ten guidelines refer to the legal definition, the exercise of the powers attaching to the right of ownership; the possession that is foundational to slavery; examples of powers attaching to the right of ownership (buying, selling or transferring a person, using a person, managing the use of a person, profiting from the use of a person, transferring a person to an heir or successor, disposal, mistreatment or neglect of a person); making a determination as to whether slavery exists; expropriation; terminology; distinction between slavery and forced labour; distinction between slavery and 'institutions and practices similar to slavery' and situation when slavery and lesser servitudes are present.

${ }^{60}$ Bellagio-Harvard Guidelines on the Legal Parameters of Slavery, Guideline 2 and 3.

${ }^{61}$ Control and freedom of choice are critical elements related to slavery circumstances, especially regarding degree of movement restriction, control of the personal belongings and consent/ understanding of the relationship nature between parties. If elements of control and ownership are accompanied with violence threats, it is central to identify the existance of slavery. David Weissbrodt, 'Slavery' Max Planck Encyclopedia of Public International Law (2015) available at opil.ouplaw.com/view/10.1093/law:epil/9780199231690/law-9780199231690-e874, accessed 02 April 2019. In C.N. and V v France, a third party intervention (Aire Centre) raised the need for clarification of the notion of control over individual in the context of slavery.

${ }^{62}$ At a minimum, a finding of slavery requires that the slave owner has some degree of control over the object which is possessed, in this case, a slave. Vijeyarasa and Bello y Villarino, supra n 25 at 70 . 


\begin{tabular}{|c|c|c|}
\hline 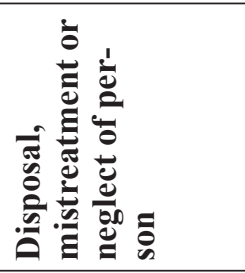 & 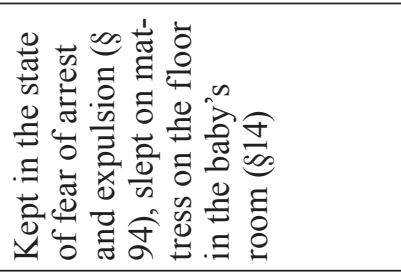 & 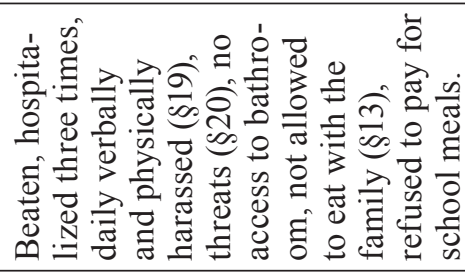 \\
\hline 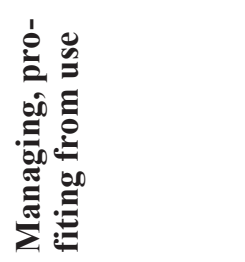 & 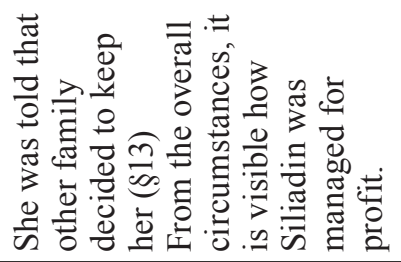 & 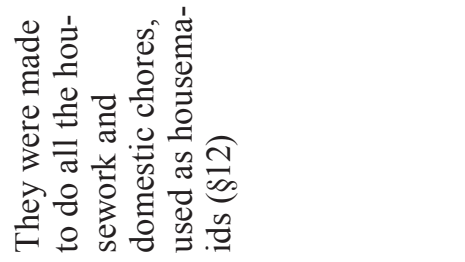 \\
\hline 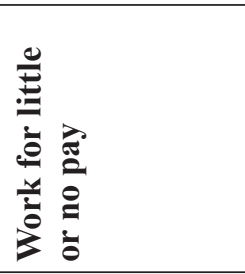 & 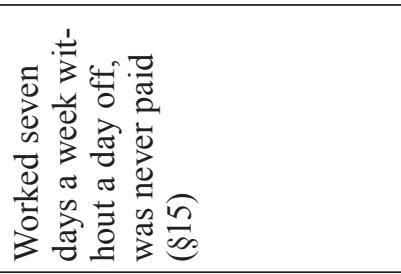 & 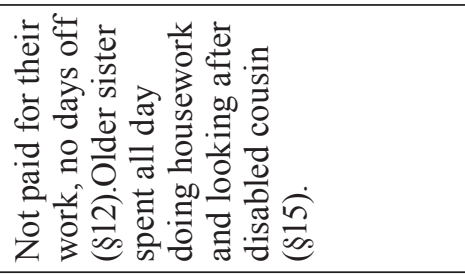 \\
\hline 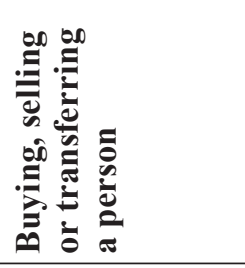 & 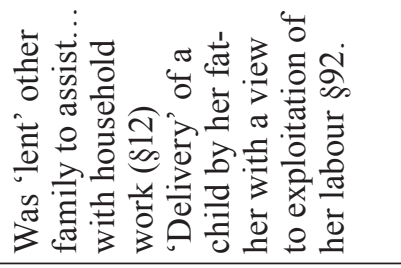 & \\
\hline 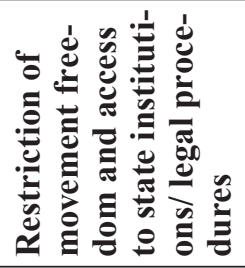 & 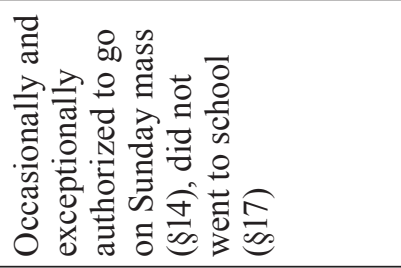 & 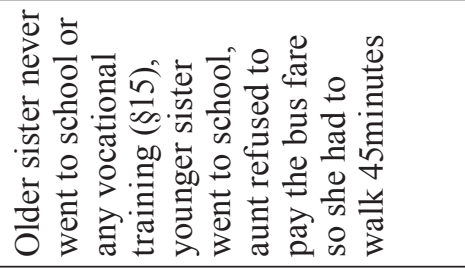 \\
\hline 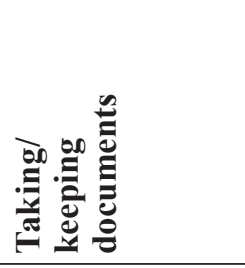 & 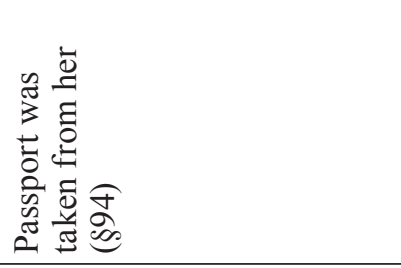 & 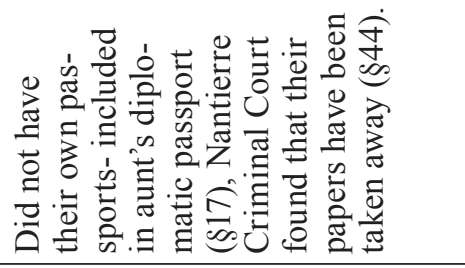 \\
\hline 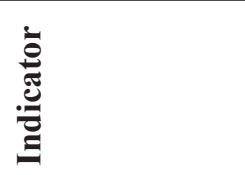 & 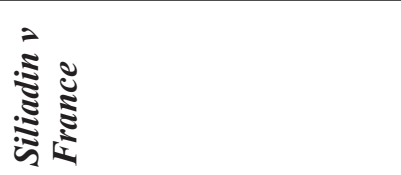 & 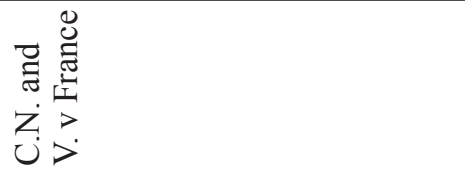 \\
\hline
\end{tabular}


perpetrators. Slavery or slavery like conduct victim can perceive as better solution compared to previously experienced situations, especially if their situation is additionally complex, i. e. they have relatives, brothers or sisters in current country (as in C.N. and V.).

The benchmark whether servitude amounts to slavery is the exercise of further control over the person, which entails placing the victim in legal limbo beyond the protection of law. ${ }^{63}$ Movement restriction, denial of access to legal procedures or institutions is direct manifest of that control, often accompanied with coercion or physical or mental constraint.

Based on the lack of genuine right of legal ownership over Siliadin (consequently reducing her to the status of an object), ${ }^{64}$ restrictive approach attached solely to de iure slavery is criticized as incorrect and out of date. ${ }^{65}$ In C.N. and V., ECtHR did not even examine slavery. Besides definition challenges, it seems there is a lack of assessment parameters. Instead, servitude was confirmed, which we discuss in the later chapter.

There are other indicators, besides the ones in BH Guidelines. Stoyanova suggests three features that lead to exercise of ownership attributes: a) making a person an object of transaction combined with denial of freedom; b) subjecting a person to the exercise of the power of possession (which also implies denial of freedom) and c) unrestricted usage of labour capacity combined with denial of freedom (which implies the exercise of the power of use). Followed with control over victim, any of these features can indicate a slavery case. ${ }^{66}$ Siliadin and $C . N$. and $V$. re-examined through Stoyanova criteria could also result with confirmation of slavery.

\subsection{A Few Notes on Servitude from Domestic Labour Exploitation Perspective}

In relevant literature and documents, servitude it is frequently connected or equated to slavery or categorized in slavery like practice. For example, it is declared that domestic slavery or servitude is the main form of slavery that is practiced in Europe today ${ }^{67}$ and has appeared as a new form of enslavement that forces thousands of victims to work without any financial reward. ${ }^{68}$ This 'new form of

${ }^{63}$ Stoyanova, supra n 28 at 286.

${ }^{64}$ Para. 122.

${ }^{65}$ Duffy, supra n 35 at 379.

66 Stoyanova, supra n 28 at 248.

${ }^{67}$ Domestic Slavery, au pairs and mail-order brides, Council of Europe (CoE) Parliamentary Assembly, Doc. 10144, Report of Committee on Equal Opportunities for Woman and Men, Rapporteur: Mr Giuseppe Gaburro, 19 April 2004, point 6.

${ }^{68}$ Domestic Slavery Report, CoE Parliamentary Assembly, Committe on Equal Oportunities for Woman and Men, Rapporteur: Mr John Connor, Doc.9102, 17 May 2001, Summary, and Council of Europe Recommendation 1523 (2001) on Domestic Slavery, point 1. 
slavery' happens when vulnerable individual forced by physical and/or moral coercion works without any substantial financial reward, deprived of liberty and in situation contrary to human dignity ${ }^{69}$ Some authors disagree with this equation, emphasizing de facto conditions that designate slavery must be exceptionally severe to distinguish it from lesser servitude; they must amount to total control or subjection, ${ }^{70}$ which points only to quantitative criteria. However, functional distinguishing criteria remain unclear. Some suggest a degree of domination ${ }^{71}$ others point out that servitude can be a slavery and vice versa. ${ }^{72}$ It is proclamated that slavery is the status of persons who are the property of another person and that servitude exposes person to duress, exercised by and/or for the benefit of another person. In denial of their liberty curtails their freedom of movement and prevents them from changing their legal status. ${ }^{73}$ The importance of servitude has increased, not only with given advantage on behalf of ECtHR, but to the view that contemporary criminal law is largely concerned with servitude while it's antecedents were concerned with slavery. ${ }^{74}$ Traditional slavery involves a notion of people as property who were owned, modern slavery rarely involves the notion of ownership. ${ }^{75}$ As seen, domestic slavery cases are declared as servitude, so it can also be perceived as a plan B solution when slavery is not confirmed. Domestic labour exploitation exists in many forms and variations; it is typically done in private homes, performing various domestic tasks such as cleaning, gardening and caring for elderly people (care workers). This type of work is gendered, customarily done by women. ${ }^{76}$ Other features include passports confiscation, placing in a state of vulnerability, dependence to their employers, unremunerated work or with disproportionate remuneration. Working conditions and accommodations are not compatible to human dignity. Some victims are kept locked up and some are in 'self-imposed confinement'. They are allowed to go out but permitted to be absent only for a certain period. ${ }^{77}$ Victims, especially children,

${ }^{69}$ Ibid, Part III, Explanatory Memorandum, point 1 and 2.

${ }^{70}$ Allain and Hickey, supra $\mathrm{n} 14$ at 931.

71 ...the degree of domination can be criterion that can facilitate the understanding of the meaning of servitude from contemporary perspective...and useful for explaining the relationship between the concepts of slavery, servitude and forced labor. Stoyanova, supra n 28 at 216-17.

${ }^{72}$ Vijeyarasa and Bello Villarino, supra n 25 at 57.

${ }^{73}$ Domestic Slavery Report, supra n 68 at points 67 and 69.

${ }^{74}$ Slavery had not been prosecuted for 200 years in the belief that law had abolished the crime and the juxtaposition of the terms slavery and servitude, which appear to distinguish the past from the present. Keane, supra $\mathrm{n} 9$ at 177.

${ }^{75}$ It is common to both types of slavery that slaves are forced to work through mental of physical threat with no or little financial reward, physically constrained or have restriction of freedom of movement and are treated in a degrading and inhumane manner. Domestic Slavery, au pairs and mail-order brides, supra $\mathrm{n} 67$ at point 4.

${ }^{76}$ Mantouvalou, supra $\mathrm{n} 23$ at 1.

77 Domestic Slavery Report, supra n 68 at Part III, Explanatory Memorandum, point 4-7. Where an employer does not expressly curtail a freedom of movement, it is restricted since a worker is aware of her/his illegal situation and is therefore at risk of being arrested or deported. 
face physical and emotional isolation, fear of the outside world, psychological problems, depression. ${ }^{78}$ There are three categories of victims: people recruited from their home country, people who are prey to traffickers who forced them into this work (many of them are children from West Africa aged 8-15 and usually work for their compatriots in Europe) ${ }^{79}$ people already undertaking domestic work and following their employer when coming to Europe. Most victims are illegal immigrants under the host country law. ${ }^{80}$ Today's slaves are predominately female and usually work in private households, starting out as migrant domestic workers au pairs or 'mail-order brides' ${ }^{81}$ On the other hand, domestic work is hard to regulate since it is performed in the privacy of employer's household and often is invisible.

The idea that Siliadin was a slave was dismissed due to the opinion there was no evident of legal ownership right. Naming this a servitude, ECtHR stated that servitude means an obligation to provide ones services imposed by the use of coercion. ${ }^{82}$ In $C . N$. and $V$., ECtHR decided that only older sister was in servitude, comprehended as a particularly serious liberty denial, an obligation to provide services imposed by the coercion use. Servitude, linked to the concept of slavery, embraces the obligation for the serf to live on another person's property and the impossibility of altering his condition. ${ }^{83}$ It corresponds to 'aggravated' compulsory labour and the dominant distinguishing feature between servitude and forced labour lies in the victims feeling that their condition is permanent and that the situation is unlikely to improve. Those responsible for this situation keep this feeling alive and the underage victim status often enables or facilitates perpetrators to act a certain way. Foreign minors are frequently unsubjected to identity checks and cannot be expelled unless they reach certain age. Many employers send them back to origin country or completely abandon them on the streets and replace them with younger victims. ${ }^{84}$ Besides Article 4, slavery/servitude as such often violates Article 3 (prohibition of torture, inhuman, degrading treatment or punishment) and Article 6 (right to access courts) ${ }^{85}$

It was undisputed that Siliadin worked for years without remuneration and against her will ${ }^{86}$ so Forced Labour Convention was applied. ${ }^{87}$ Confirming forced

${ }^{78}$ Ibid, points $39-46$.

${ }^{79}$ Domestic Slavery, au pairs and mail-order brides, supra $\mathrm{n} 67$ at point 9.

${ }^{80}$ Domestic Slavery Report, supra n 68 at points 19-22.

${ }^{81}$ Domestic Slavery, au pairs and mail-order brides, supra $n 67$ at Summary.

${ }^{82}$ Para. 124. In Supplementary Slavery Convention, servitude as a concept was not defined but there is a definition of a person of servile status in Art. 7(b). This is the person in the condition or status resulting from any of the institutions or practices from Art. 1 (debt bondage, serfdom, servile marriage or child servitude).

${ }^{83}$ Paras. 89- 90.

${ }^{84}$ Domestic Slavery Report, supra n 68 at point 25.

${ }^{85}$ Council of Europe Recommendation 1523 (2001) on Domestic Slavery, point 3.

86 Para. 114.

${ }^{87}$ Convention Concerning Forced or Compulsory Labour, 1930 (No.29). Forced or compulsory labor means all work or service exacted from any person under the menace of any penalty and for which the person has not offered himself voluntarily. 
labour, her position was equated with the one where menace of threat exist ('perceived seriousness of the threat') together with the fact that labour was not given voluntarily since she actually did not have a choice. ${ }^{88}$ In $C$. $N$. and $V$. the Court stressed the forced labour factors that point out the notion of 'disproportionate burden' only regarding the older sister. ${ }^{89}$

\section{CONCLUDING REMARKS- NEW CHALLENGES FOR ARTICLE 4 IN DAYS TO COME}

Final thoughts evolve around shown slavery reasoning- is it an adequate approach appropriate to nowadays society conditions and can it be possible to ensure the ECHR protection level by retaining this attitude? The outlined judgments reflect unfunctional and restrictive ECtHR attitude, since slavery per se was not (yet) confirmed due to traditional definition guided by Slavery Convention from the beginning of $20^{\text {th }}$ century. This resulted in missed opportunity to contribute to new, up to date interpretation. Society circumstances have influenced the slavery understanding directing a need for a contemporary context, consideration of a unprecedented scope of exploitation relations, cases without previous similarities or known patterns, recent social conditions and migrations...etc. ${ }^{90}$

${ }^{88}$ Paras. 118-119. ECtHR corectly accepts the wider concept of menace which comprehends the loss of different rights or privileges as well as the threat of deportation (that victim took seriously).

${ }^{89}$ Para. 74 regarding the type and the amount of work involved. In this case, the first aplicant was forced to work so hard that without her Ms would have to employ and pay a proffesional house cleaner. Even though this is not the paper topic (in the narrow sense), but it is appropriate to mention the cases of forced marriages which are in the national context included in the notion of servitude. In that sense, Croatian courts (Supreme Court VSRH, I Kž 274/13-7 and County Court Sisak KMP-33/2011) wrongfully refused to apply the trafficking provision to case of arranged marriage of 14-year-old girl, demonstrating the difficulties in human trafficking recognition. County and Supreme Court in this case were led by the fact that the exploitation purpose was not yet achieved. The decisions were made without taking into account that that human trafficking puts emphasis not on the ultimate exploitative conditions but on the process that leads to exploitation and the fact that human trafficking falls under the scope of Art. 4 ECHR. See, M. Munivrana Vajda, Sudska praksa /Court practice, 24 Hrvatski ljetopis za kaznene znanosti i praksu/Croatian Annual for Criminal Law Sciences and Practice, (2017) pp. 723-728.

${ }^{90}$ Conventions of 1926 and 1956 do not foresee a body responsible for the interpretation of the Convention provisions and to receive reports from the States Parties on the fulfillment of their obligations. The 1956 Convention foresaw these tasks to the UN Economic and Social Council without a court body, and in 2008, the Human Rights Council determined the existence of a special rapporteur for slavery (Resolution 6/14 of 28 September 2007). All major Human Rights treaties after ICCPR (1966) have provided authoritative body responsible for periodic report review. Urmila Bhoola and Kari Panaccione 'Slavery Crimes and the Mandate of the United Nations Special Rapporteur on Contemporary Forms of Slavery' 14 Journal of International Criminal Justice (2016) 363-373, at 368. Also, Weissbrodt, supra 50. 
Other mentioned courts have already set their legal standards, extending the international concept of enslavement, providing assessing factors that would be indicative to slavery qualification ${ }^{91}$ as well as openly declared de iure slavery inappropriate. As often stated in the judgments, ECHR is a living instrument that is to be interpreted in the light of contemporary conditions where ECtHR seems to omit more recent positions and documents in this topic. This reflects on many rights that are violated by the slavery establishment - the right to freedom of decision, freedom of movement, free work and choice of profession, dignity, a range of particular rights aimed at children such as the right to education, special protection and the best interest of the child... The general lack of precision of notions belonging to Article 4 condition this situation.

However, in the judgment of M. and others v. Italy and Bulgaria, ${ }^{92}$ ECtHR has subtly modified the expression given in Siliadin....to classic definition of slavery, which required the exercise of a genuine right of ownership and reduction to of the status of the individual concerned to an object. ${ }^{93}$ Stoyanova correctly observes the lack of the term legal in the expression of genuine right of ownership and lack of the use of expression status or an object. ${ }^{94}$

In the challenges of the contemporary age, the 1926 slavery definition can represent a good starting point, taking into account new interpretation need, stepping back from property/ownership comparison and supplementing it with the de facto slavery features. It cannot be tenable striving to pinpoint it with legally impossible or unviable concept. ${ }^{95}$ It is more suitable to the spirit of time to advance the existing definition by analysing the behaviour of perpetrators directed at possessing attributes by establishing control and exploitation of victim. BH Guidelines have certainly contributed to better understanding, as well as presented ICTY and HCA judgement. The term significant deprivation of a personal liberty can be improved. Starting from the thesis of considerable control of personal freedom (movement, choice and decision-making) as sufficient for slavery confirmation, restriction would seem as acceptable term. In that sense, it would be possible to interpret slavery as a significant restriction of personal freedom creating dependence to a considerable extent, directed at exploitation in various ways. ${ }^{96}$

Domestic labour exploitation found in ECtHR judgments, it is called servitude. The notion per se as well as related mentioned documents point that this is a form of (modern) slavery. For delimiting slavery from servitude, the ECtHR

${ }^{91}$ Harmen van der Wilt, 'Slavery Prosecutions in International Criminal Jurisdiction' 14 Journal of International Criminal Justice (2016) 269-283 at p. 275 and 282.

${ }^{92}$ Application number 40020/03, 31 July 2012.

${ }^{93}$ Para. 149.

${ }^{94}$ Stoyanova, supra n 28 at 247.

${ }^{95}$ Herceg Pakšić and Jukić supra n 32.

${ }^{96}$ See in ibid at 289-290. 
uses the concept of ownership (as a constituent element of slavery). Sociology authors, over quarter of century ago, suggested that ownership is no longer part of slavery and is wrong to associate them.${ }^{97}$ Mantouvalou offers an interesting example of how professional athletes are sold but are not considered slaves. ${ }^{98}$

Despite lack of precision in notions that expressis verbis belong to Article 4, ECtHR continues to enlarge the protective scope. Trafficking in human beings was included in 2010 due to its nature connected to slavery, as a form of modern slavery. In the recent judgement S. M. v Croatia, ${ }^{99}$ ECtHR decided to place 'exploitation of prostitution' to this scope. Stressing here the obligation to interpret Convention in the light of present-day conditions, it ruled that not only trafficking itself, but also exploitation of prostitution fell within the scope of Article 4, considering it unnecessary to identify whether the treatment of which the applicant complained constituted slavery, servitude or forced and compulsory labour. ${ }^{100}$

Restrictive stance on 'core' notions but rather liberal for newcomers, without affiliation explaining, is not without objections. Besides other risen challenges, the last mentioned judgement did not explain the merits-why does exploitation for prostitution, in S. M. circumstances, belong to Article 4? This is undoubtedly a significant extensive reach. Grounded solely on the fact that national authorities had given the applicant the status of victims of trafficking follows res ipsa loqitur reasoning, which here does not seem the satisfying path. ${ }^{101}$

In the end, on new possible discussion areas. Perhaps it would benefit to observe belonging notions of Article 4 from different perspective: not as gradation based ad valorem violation level, but rather as the existence of various forms of slavery. The wide range of often-used 'modern slavery' phrase supports this simplified view. On another hand, another challenge: can we think about the separate and autonomous definition of the servitude without mere connection with slavery of lower level that serves as the backup application. This has value regarding various other manifestations of so-called modern slavery, an indefinite syntagm

97 Orlando Patterson, Slavery and social death: A comparative study (Harvard University Press, 1982), pp. 1-14

${ }^{98}$ Mantouvalou, supra $\mathrm{n} 11$ at 6.

${ }^{99}$ Application no 60561/14, 19 July 2018. The case concerned a Croatian woman's complaint that she had been forced into prostitution. In national procedure, there was no sufficient evidence on coercion element. She alleged in particular that the authorities had failed to respond adequately to her complaint and that Croatia lacked a proper legal framework to deal with such issues. The Court found that Croatian authorities did not fulfil their procedural obligations under Art. 4 of the Convention. There has accordingly been a violation of Art. 4 of the Convention.

${ }^{100}$ Para. 54 of judgement.

${ }^{101}$ Besides merits challenges (insufficient explanation and problematic reasoning on scope expansion), there are admissibility issues (ECtHR deciding on facts not risen by applicant as a form of ultra vires doctrine), and on compliance regarding procedural obligation. See further in dissenting opinion of judge Koskelo. 
that today does not have its exact limits. To conclude, we cite the excerpt from Oswald Pohl case: Slavery may exist even without torture. '...' they are still slaves if without lawful process they are deprived of their freedom by forceful restraint. '...' We might eliminate all proof of ill-treatment, overlook the starvation, beatings, and other barbarous acts, but the admitted fact of slavery - compulsory uncompensated labour - would still remain. '...' Involuntary servitude, even if tempered by humane treatment, is still slavery. ${ }^{102}$

\section{REFERENCES}

\section{Articles, books:}

Angelika Kartusch, Domestic Workers in Diplomats' Households Rights Violations and Access to Justice in the Context of Diplomatic Immunity. Analysis of Practice in Six European Countries. German Institute for Human Rights (2011).

Ariela J. Gross and Chantal Thomas, 'The New Abolitionism, International Law and the Memory of Slavery' 35 Law and History Review (2017) 99-118.

Barbara Herceg Pakšić and Miroslav Jukić, 'Primjena konvencijskog prava u području zabrane ropstva i prisilnog rada: Europski standardi i hrvatska postignuća' / ECHR Prohibition of Slavery and Forced Labour: European Standards and Croatian Accomplishments/23 Hrvatski ljetopis za kaznene znanosti i praksu, (2016). David Keane, 'Abolitionist At Heart but not in Action, Slavery, Servitude and the Status of Art. 4 ECHR in Irish Law' 50 Irish Jurist (2013) 166-198.

David Tolbert and Laura A. Smith, 2016. 'Complementarity and the Investigation and Prosecution of Slavery Crimes'14 Journal of International Criminal Justice (2016) 429-451.

David Weissbrodt, 'Slavery' Max Planck Encyclopedia of Public International Law (2015) available at opil.ouplaw.com/view/10.1093/law:epil/9780199231690/law9780199231690-e874, accessed 02 April 2019

David Weissbrodt, and Cheryl Heilman, 'Defining Torture and Cruel, Inhuman, and Degrading Treatment' 29 Law \& Inequality, (2011) 343-394

Harmen van der Wilt, 'Slavery Prosecutions in International Criminal Jurisdiction' 14 Journal of International Criminal Justice (2016) 269-283

Helen Duffy, 'Litigating Modern Day Slavery in Regional Courts: A Nascent Contribution' 14 Journal of International Criminal Justice (2016) 375-403.

Irina Kolodizner, 'R v Tang: Developing an Australian Anti-Slavery Jurisprudence' 31 Sydney Law Review (2009) 487-497, at pp. 491-495.

Jacqueline Bhabha and Wendy Young, 'Not Adults in Miniature: Unaccompanied Child Asylum Seekers and the New US Guidelines'11 International Journal of Refugee Law (1999) 84-125.

102 US v Oswald Pohl and Others, Judgment of 3 November 1947, reprinted in Trials of War Criminals before the Nurenberg Military Tribunals under Control Council No. 10, Vol 5 (1997), at 970 . 
Jean Allain and Robin Hickey, 'Property and Definition of Slavery' 61 International and Comparative Law Quarterly (2012) 915-938.

Jean Allain, 'R v Tang, Clarifying the Definition of Slavery in International Law'10 Melbourne Journal of International Law 10 (2009) pp. 246-255.

Jean Allain, 'The Definition of Slavery in International Law'52 Howard Law Journal (2009) 239-275.

Jean Allan and Kevin Bales, 'Slavery and its Definitions'14 Global Dialogue 14 Research Paper No. 12-06, (2012) pp. 3-7, available at hydra.hull.ac.uk/assets/ hull:9986/content, accessed 15 March 2019.

Lucas Knott, 'Unocal Revisited: On the difference between Slavery and Forced Labor in International Law' 28 Wisconsin International Law Journal (2010) 201-233.

M. Cherif Bassiouni, 'International Crimes: Jus Cogens and Obligations Erga Omnes' 4 Law and Contemporary Problems (2013) pp. 63-74.

Maja Munivrana Vajda, Sudska praksa /Court practice, 24 Hrvatski ljetopis za kaznene znanosti i praksu/Croatian Annual for Criminal Law Sciences and Practice, (2017) pp. 723-728.

Manfred Nowak and Elizabeth McArthur, 'The distinction between torture and cruel, inhuman or degrading treatment' 16 Torture (2006) 147-151.

Mary E. Crock, 'Of Relative Rights and Putative Children: Rethinking the Critical Framework for the Protection of Refugee Children and Youth' 54 Australian International Law Journal (2013) 33-53

Orlando Patterson, Slavery and social death: A comparative study (Harvard University Press, 1982), pp. 1-14

Ramona Vijeyarasa and Jose Miguel Bello Villarino, 'Modern Day Slavery-a Judicial Catchall for Trafficking, Slavery and Labour Exploitation: A Critique of Tang and Rantsev' 38 Journal of International Law and International Relation (2013) 38-76.

Urmila Bhoola and Kari Panaccione 'Slavery Crimes and the Mandate of the United Nations Special Rapporteur on Contemporary Forms of Slavery' 14 Journal of International Criminal Justice (2016) 363-373, at 368.

Virginia Mantouvalou, 'The Many Faces of Slavery: the Example of Domestic Work' 2012,www.academia.edu/1522698/The_Many_Faces_of_Slavery_The_Example_of_Domestic_Work, accessed 10 April 2019

Vladislava Stoyanova, 'Article 4 of ECHR and the obligation of Criminalizing Slavery, Servitude, Forced labour and Human Trafficking' 3 Cambridge Journal of International and Comparative Law (2014) 407-443.

Vladislava Stoyanova, Human Trafficking and Slavery Reconsidered, Conceptual Limits and States'Positive Obligations, Cambridge University Press, 2017.

Wiliam A. Schabas, The European Convention of Human Rights, A Commentary, Oxford University Press, 2015.

\section{Acts and documents:}

7th General Report on GRETA Activities. March 2018. Available online at rm.coe. int/greta-2018-1-7gr-en/16807af20e

Bellagio-Harvard Guidelines on the Legal Parameters of Slavery. Ten guidelines aimed at clarifying the slavery determination based on Art. 1 of the 1296 Slavery Convention and Art. 7 (a) of the 1956 Supplementary Convention. www.law. 
qub.ac.uk/schools/SchoolofLaw/FileStore/Filetoupload,651854,en.pdf, accessed 10 April 2019.

Convention Concerning Forced or Compulsory Labour, 1930 (No.29).

Convention on the Rights of the Child, United Nations, 1989.

Convention to Suppress the Slave Trade and Slavery, 1926, 46 Stat. 2183, Treaty Series 778.

Council of Europe Recommendation 1523 (2001) on Domestic Slavery

Domestic Slavery Report, CoE Parliamentary Assembly, Committe on Equal Oportunities for Woman and Men, Rapporteur: Mr John Connor, Doc.9102, 17 May 2001, Summary, and Council of Europe Recommendation 1523 (2001) on Domestic Slavery

Domestic Slavery, au pairs and mail-order brides, Council of Europe (CoE) Parliamentary Assembly, Doc. 10144, Report of Committee on Equal Opportunities for Woman and Men, Rapporteur: Mr Giuseppe Gaburro, 19 April 2004, point 6.

European Convention on Human Rights and Fundamental Freedoms, Council of Europe 1950.

Guide on Article 4 of the Convention - Prohibition of slavery and forced labour, European Court of Human Rights, 31 December 2018, at 6.

ILO Convention (No. 182) concerning the Prohibition and Immediate Action for the Elimination of the Worst Forms of Child Labour, Geneva on 17 June 1999 ([2007] ATS 38).

Modern Slavery Act No. 153, 2018, C2018A00153.

Protocol on the Prevention, Suppression and Punishment of Trafficking in Persons, especially Women and Children, the Convention on the Abolition of Slavery Application No 67724/09, 11 October 2012.

Protocol to Prevent, Suppress and Punish Trafficking in Persons, Especially Women and Children, supplementing the United Nations Convention against Transnational Organized Crime, New York on 15 November 2000 ([2005] ATS 27)

Ready for future challenges-Reinforcing the Council of Europe, Report by the Secretary General for the Ministerial Session in Helsinki, 16-17 May 2019, April 2019.

Report of the Special Rapporteur on Contemporary Forms of Slavery, including its causes and consequences, Gulnara, United Nations, General Assembly, A/ HRC/15/20/Add.2, 16 August 2010, pp 2-4. David Weissbrodt and Anti-Slavery International (Michael Dottridge). Abolishing Slavery and its Contemporary Forms, Office of the United Nations High Commissioner for Human Rights. United Nations New York and Geneva HR/PUB/02/4 2002.

Rome statute of the International Criminal Court 1998

The Supplementary Convention on the Abolition of Slavery, The Slave Trade and Institutions and Practices similar to Slavery 1956, UNTS 266, I. Nos 3822-3833.

UN Human Rights Council (2017) Report of the Special Rapporteur on contemporary forms of slavery including its causes and consequences, A/HRC/36/43.

United Nations, Committee on Migrant Workers 2011: General Comment on Migrant Domestic Workers: CMW/C/GC/1, 23 February 2011. 


\section{Judgements}

Croatian County Court Sisak KMP-33/2011

Croatian Supreme Court VSRH, I Kž 274/13-7

European Court of Human Rights Application number, M. and others v Italy and Bulgaria, Application No 40020/03, 31 July 2012

European Court of Human Rights, C. N. and V. v France, Application No 67724/09, 11 October 2012.

European Court of Human Rights, Siliadin v France, Application No 73316/01, 26 July 2005.

International Court of Justice, Barcelona Traction, Light and Power Company, Limited, Belgium v. Spain, Second Phase, 05 February 1970. Available at www.icj-cij. org/files/case-related/50/050-19700205-JUD-01-00-EN.pdf 1212 2017, p. 32, paras. 33-34, accessed 20 August 2019

International Tribunal for the Prosecution of Persons Responsible for Serious Violations of International Humanitarian Law Committed in the Territory of the Former Yugoslavia since 1991, IT-96-23\& IT-96-23/1-A, 12 June 2002. Judgment of June 2002, Prosecutor v Dragoljub Kunarac, Radomir Kovač and Zoran Vuković, available at www.icty.org/x/cases/kunarac/acjug/en/kun-aj020612e.pdf, accessed 13 September 2019

The Queen v Tang, [2008] HCA 39, 28 August 2008, M5/2008. Available at www. austlii.edu.au/cgi-bin/sinodisp/au/cases/cth/HCA/2008/39.html?stem=0\&synonyms $=0 \&$ query $=$ title $(\% 222008 \% 20 \mathrm{HCA} \% 2039 \% 22$, accessed 13 January 2019 .

\section{Websites:}

Ramachandra Komala, 'Australia Starts Tackling Modern Slavery. New South Wales Adds Penalties for Offenders Under State Law' Human Rights Watch, available on www.hrw.org/news/2019/01/09/australia-starts-tackling-modern-slavery, accessed 25 September 2019.

www.crin.org/en/library/publications/forms-violence-slavery, accessed 17 July 2019. www.crin.org/en/library/publications/france-exploitation-case-sees-slavery-criminalised-last, accessed 12 December 2018

www.crin.org/en/library/publications/united-kingdom-child-domestic-slavery-growing-phenomenon-uk, accessed 17 July 2019.

www.euronews.com/2017/04/28/hungary-completes-new-anti-migrant-border-fencewith-serbia, accessed 25 June 2019.

www.legislation.gov.uk/ukpga/2015/30/contents/enacted, accessed 25 August 2019. www.theguardian.com/world/2017/jun/21/trial-begins-over-deaths-of-71-migrantsin-refrigerated-lorry, accessed 17 July 2019. 
Dr Barbara P. Herceg Pakšić, docent

Univerzitet J. J. Štrosmajer u Osijeku

Pravni fakultet u Osijeku

bhercegpaksic@gmail.com

\section{Prilog raspravi o ropstvu: rad djece migranata u središtu pažnje ${ }^{103}$}

Sažetak: Ropstvo te s njim povezana praksa prividno su zaboravljeni fenomeni za koje se često smatra kako pripadaju prošlosti. Ipak, migrantska kretanja aktualiziraju ovu zabranjenu praksu te ona dobiva nove obrise. Svrha je ovog rada (raz)motriti specifične slučajeve koji su svoj epilog našli pred Europskim sudom za ljudska prava a u kojima su žrtve bile djeca. Uzimajući u obzir suvremena razmatranja o ropstvu i sličnim odnosima, propitujemo ključne elemente povezane s pojmom ropstva pri čemu je naglasak stavljen na nedostatno funkcionalna određenja, nesigurnost kriterija procjene te usporedbu s presudama drugih sudova. Obzirom da se Europska konvencija za zaštitu ljudskih prava i temeljnih sloboda opisuje kao najsnažniji mehanizam zaštite ljudskih prava sa značajnim učinkom na nacionalne sustave, tragamo za oživotvorenjem konvencijske zabrane iz članka 4, analiziramo recentni razvoj na tom području nudeći suvremenu perspektivu promatranja ropstva.

Ključne riječi: ropstvo, servitut, djeca, Europska konvencija za zaštitu ljudskih prava, kućni rad.

Datum prijema rada: 22.11.2019.

${ }^{103}$ Rad je prezentovan na Međunarodnoj naučnoj konferenciji Pravna tradicija i novi pravni izazovi, održanoj 03. i 04.10.2019. godine na Pravnom fakultetu Univerziteta u Novom Sadu. 